$\underline{\text { Supporting Information (SI) }}$

\title{
Premagnetization for Enhancing the Reactivity of Multiple Zerovalent Iron Samples toward Various Contaminants
}

\author{
Jinxiang Li, Hejie Qin, and Xiaohong Guan* \\ State Key Laboratory of Pollution Control and Resources Reuse, College of \\ Environmental Science and Engineering, Tongji University, Shanghai 200092, \\ People's Republic of China
}

*Author to whom correspondence should be addressed

Xiaohong Guan, email: guanxh@tongji.edu.cn; phone: +86-21-65980956; Fax:

+86-21-65986313.

Prepared for Environmental Science \& Technology

Number of pages (including this page): 28

Number of Tables: 4

Number of Figures: 19 


\section{Summary}

Figure S1. SEM images of the ZVI samples employed in this study. (Page S6)

Figure S2. Particle size distribution of the ZVI samples employed in this study. (Page S7)

Figure S3. Raman spectra of the ZVI samples employed in this study. (Page S8)

Figure S4. Magnetic hysteresis loops of the pristine ZVI recorded at $300 \mathrm{~K}\left(\mathrm{~B}_{\max }=\right.$ $500 \mathrm{mT}$ ). The inset shows the behavior of the hysteresis loops in the low-field region. (Page S9)

Figure S5. The kinetics of $\mathrm{AR} 27, \mathrm{~Pb} 2+, \mathrm{Cu} 2+, \mathrm{Se} 4+, \mathrm{Ag}+$ and $\mathrm{Cr} 6+$ removal by Pri-ZVI and Mag-ZVI (Symbols are experimental data and dash lines are simulation results with the pseudo-first-order kinetic model). Reaction conditions: $\left[\mathrm{Fe}^{0}\right]=0.50 \mathrm{~g} \mathrm{~L}^{-1},[\mathrm{NaAc}-\mathrm{HAc}]=0.10 \mathrm{M}(\mathrm{pH} 4.0),[$ Intensity of $\mathrm{MF}$ for premagnetization] $=500 \mathrm{mT}, \mathrm{t}_{\text {premag }}=2 \mathrm{~min}, \mathrm{~T}=25 \pm 1{ }^{\circ} \mathrm{C}$. (Page S10)

Figure S6. Release of dissolved $\mathrm{Fe}(\mathrm{II})$ during $\mathrm{Pb} 2+, \mathrm{Cu} 2+, \mathrm{Se} 4+$ and $\mathrm{Ag}+$ removal by Pri-ZVI/Mag-ZVI samples. (Page S11)

Figure S7. Bubble plot of the promotion factors ( $\mathrm{f}=k_{\mathrm{Mag}} / k_{\mathrm{Pri}}$, represented as ring size) for contaminants sequestration due to premagnetization plotted versus contaminants (ordinate) and the types of ZVI (abcissa). (Page S12)

Figure S8. Scatter plot matrix of rate constants $\left(k_{\mathrm{obs}}, \mathrm{min}^{-1}\right)$ for all combinations of contaminants removal by Pri-ZVI and Mag-ZVI samples. Each symbol in each plot represents one of the eight types of ZVI. (Page S13) 
Figure S9. Rate constants $\left(k_{\mathrm{SA}}, \mathrm{L} \mathrm{m}^{-2} \mathrm{~min}^{-1}\right)$ of $\mathrm{Cr} 6+, \mathrm{Ag}+, \mathrm{Se} 4+, \mathrm{Cu} 2+, \mathrm{Pb} 2+$ and AR27 sequestrated by Pri-ZVI (left ordinate) and Mag-ZVI (right ordinate). (Page S14)

Figure S10. Kinetics of $\mathrm{Pb} 2+(\mathrm{a})$ and $\mathrm{Cu} 2+$ (b) removal by Mag-ZVI (ZVI-S1, specific surface area $(\mathrm{SSA})=0.40 \mathrm{~m}^{2} \mathrm{~g}^{-1}$ and ZVI-S2, SSA $\left.=2.41 \mathrm{~m}^{2} \mathrm{~g}^{-1}\right)$. Symbols are experimental data and dash lines are simulation results with the pseudo-first-order kinetic model. Reaction conditions: $\left[\mathrm{Fe}^{0}\right]=0.50 \mathrm{~g}$ $\mathrm{L}^{-1},[\mathrm{Cu} 2+/ \mathrm{Pb} 2+]=0.20 \mathrm{mM},[\mathrm{NaAc}-\mathrm{HAc}]=0.10 \mathrm{M}(\mathrm{pH} 4.0),[$ Intensity of $\mathrm{MF}$ for premagnetization] $=500 \mathrm{mT}, \mathrm{t}_{\text {premag }}=2 \mathrm{~min}, \mathrm{~T}=25 \pm 1{ }^{\circ} \mathrm{C}$. (Page S15)

Figure S11. The relationship between the average rate constants (Avg $\log k_{\mathrm{SA}}, \mathrm{L} \mathrm{m}^{-2}$ $\min ^{-1}$ ) of each contaminant by all types of ZVI samples and the redox potentials (E, V) of these contaminants (abcissa). (Page S16)

Figure S12. Rate constants $\left(\lg k_{\mathrm{SA}}, \mathrm{L} \mathrm{m}^{-2} \mathrm{~min}^{-1}\right)$ for disappearance of $\mathrm{Cr} 6+, \mathrm{Ag}+$, Se4+, Cu2+, Pb2+ and AR27 by Pri-ZVI (a) and Mag-ZVI (b). (Page S17)

Figure S13. The kinetics of Fe(II) release from the Pri-ZVI and Mag-ZVI samples employed in this study without the presence of contaminants. The solid lines are the results of simulation with zero-order rate law and the numbers are the observed rate constants of $\mathrm{Fe}(\mathrm{II})$ release from Pri-ZVI and Mag-ZVI samples. Reaction conditions: $\left[\mathrm{Fe}^{0}\right]=0.50 \mathrm{~g} \mathrm{~L}{ }^{-1},[\mathrm{NaAc}-\mathrm{HAc}]=$ $0.10 \mathrm{M}(\mathrm{pH}=4.0),[$ Intensity of $\mathrm{MF}$ for premagnetization] $=500 \mathrm{mT}$, $\mathrm{t}_{\text {premag }}=2 \min , \mathrm{T}=25 \pm 1{ }^{\circ} \mathrm{C} .($ Page S18) 
Figure S14. The correlation of the average rate constants $\left(\operatorname{Avg} \lg k_{\mathrm{SA}}, \mathrm{L} \mathrm{m}^{-2} \mathrm{~min}^{-1}\right)$ for all combinations of contaminants with the $\mathrm{Fe}(\mathrm{II})$ release rates $\left(\lg k_{\mathrm{Fe}(\mathrm{II}) \text { releaseSA }}, \mathrm{mg} \mathrm{m}^{-2} \mathrm{~min}^{-1}\right)$ of the Pri-ZVI and Mag-ZVI from different origins. (Page S19)

Figure S15. (a) The kinetics of Fe(II) release from two Mag-ZVI samples (ZVI-S1, $\mathrm{SSA}=0.40 \mathrm{~m}^{2} \mathrm{~g}^{-1}$ and ZVI-S2, SSA $=2.41 \mathrm{~m}^{2} \mathrm{~g}^{-1}$ ) without presence of contaminants; (b) The consistency of the experimentally determined values of $\lg k_{\mathrm{Cu} 2+\mathrm{SA}}$ by two Mag-ZVI samples (not included in Figure 2(b)) with those predicted from the correlation illustrated in Figure 4. Reaction conditions: $\left[\mathrm{Fe}^{0}\right]=0.50 \mathrm{~g} \mathrm{~L}^{-1},[\mathrm{NaAc}-\mathrm{HAc}]=0.10 \mathrm{M}(\mathrm{pH}=4.0),[$ Intensity of $\mathrm{MF}$ for premagnetization] $=500 \mathrm{mT}, \mathrm{t}_{\text {premag }}=2 \mathrm{~min}, \mathrm{~T}=25 \pm 1{ }^{\circ} \mathrm{C}$, $[\mathrm{Cu} 2+]=0 \mathrm{mM}$ for $(\mathrm{a})$ and $[\mathrm{Cu} 2+]=0.20 \mathrm{mM}$ for $(\mathrm{b})$. (Page S20)

Figure S16. Kinetics of $\mathrm{Cu} 2+$ removal by various Mag-ZVI samples at $\mathrm{pH} 5.0$ (Symbols are experimental data and dash lines are simulation results with the pseudo-first-order kinetic model). Reaction conditions: $\left[\mathrm{Fe}^{0}\right]=0.50 \mathrm{~g}$ $\mathrm{L}^{-1},[\mathrm{Cu} 2+]=0.20 \mathrm{mM},[\mathrm{NaAc}-\mathrm{HAc}]=0.10 \mathrm{M}(\mathrm{pH} 5.0),[$ Intensity of MF for premagnetization $]=500 \mathrm{mT}, \mathrm{t}_{\text {premag }}=2 \mathrm{~min}, \mathrm{~T}=25 \pm 1^{\circ} \mathrm{C} .($ Page $\mathrm{S} 21)$

Figure S17. The correlation of the specific rate constants $\left(\lg k_{\mathrm{Mag} \mathrm{SA}}, \mathrm{L} \mathrm{m}^{-2} \mathrm{~min}^{-1}\right)$ for $\mathrm{Cu} 2+$ removal by Mag-ZVI ( $\mathrm{pH} 5.0$ ) with the intrinsic reactivity of Mag-ZVI samples ( $\lg k_{\text {Mag Fe(II)release SA }}, \mathrm{mg} \mathrm{m}^{-2} \min ^{-1}$ ). (Page S22)

Figure S18. The kinetics of Fe(II) release from the Mag-ZVI samples under nitrogen-purging conditions without the presence of contaminants. The 
dashed lines are the results of simulation with zero-order rate law and the numbers are the observed rate constants of $\mathrm{Fe}(\mathrm{II})$ release from the Mag-ZVI samples. Reaction conditions: $\left[\mathrm{Fe}^{0}\right]=0.50 \mathrm{~g} \mathrm{~L}^{-1},[\mathrm{NaAc}-\mathrm{HAc}]=$ $0.10 \mathrm{M}(\mathrm{pH}=4.0)$, [Intensity of $\mathrm{MF}$ for premagnetization $]=500 \mathrm{mT}$, $\mathrm{t}_{\text {premag }}=2 \min , \mathrm{T}=25 \pm 1^{\circ} \mathrm{C} .($ Page $\mathrm{S} 23)$

Figure S19. Correlation of the Fe(II) release rates of various Mag-ZVI samples under anoxic conditions (purged with nitrogen, $\lg k^{\prime \prime}$ Mag Fe(II)release SA, mg $\mathrm{m}^{-2}$ $\min ^{-1}$ ) with the intrinsic reactivity (open to the air, $\lg k_{\mathrm{Mag} \text { Fe(II)release SA, }}$ $\mathrm{mg} \mathrm{m} \mathrm{min}^{-1}$ ) of these Mag-ZVI samples. (Page S24)

Table S1. Properties of contaminants employed in this study $(0.10 \mathrm{M}$ NaAc-HAc buffer system, $\mathrm{pH} 4.0)$. (Page S25)

Table S2. The mean observed rate constants $\left(k_{\mathrm{obs}}, \min ^{-1}\right)$ for contaminants sequestration by Pri-ZVI and Mag-ZVI. (Page S26)

Table S3. Statistics of the normal distribution calculated by the One-Sample Kolmogorov-Smirnov Test. (Page S27)

Table S4. Summary of the statistical significances derived from the Pearson correlation and Spearman correlation. (Page S28) 


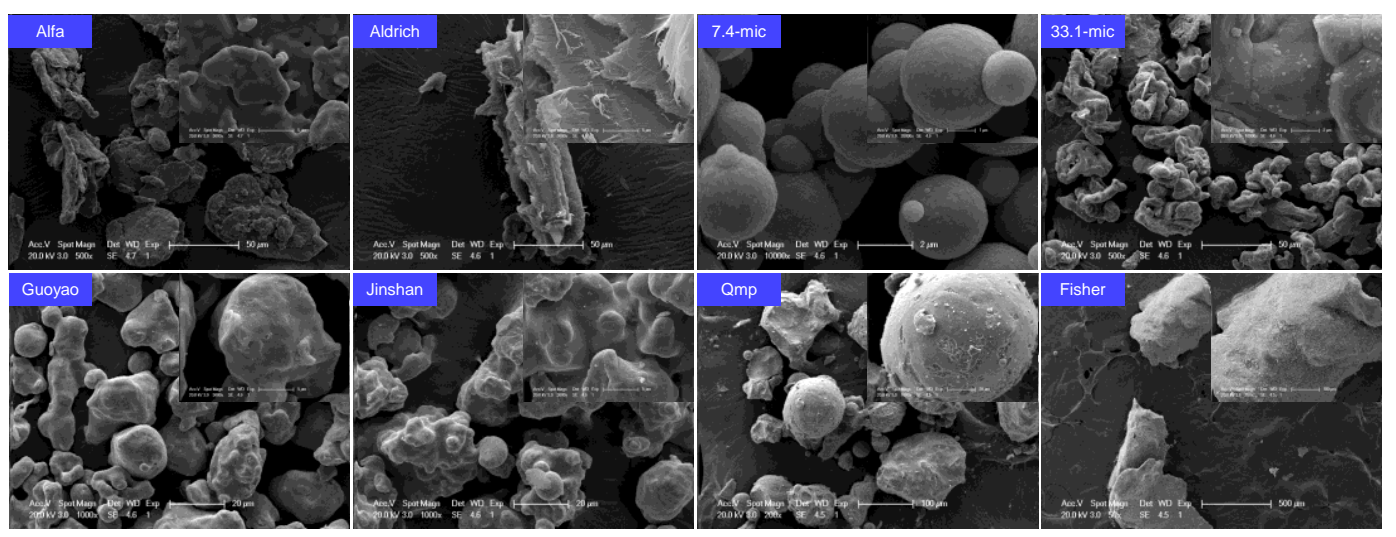

Figure S1. SEM images of the ZVI samples employed in this study. 

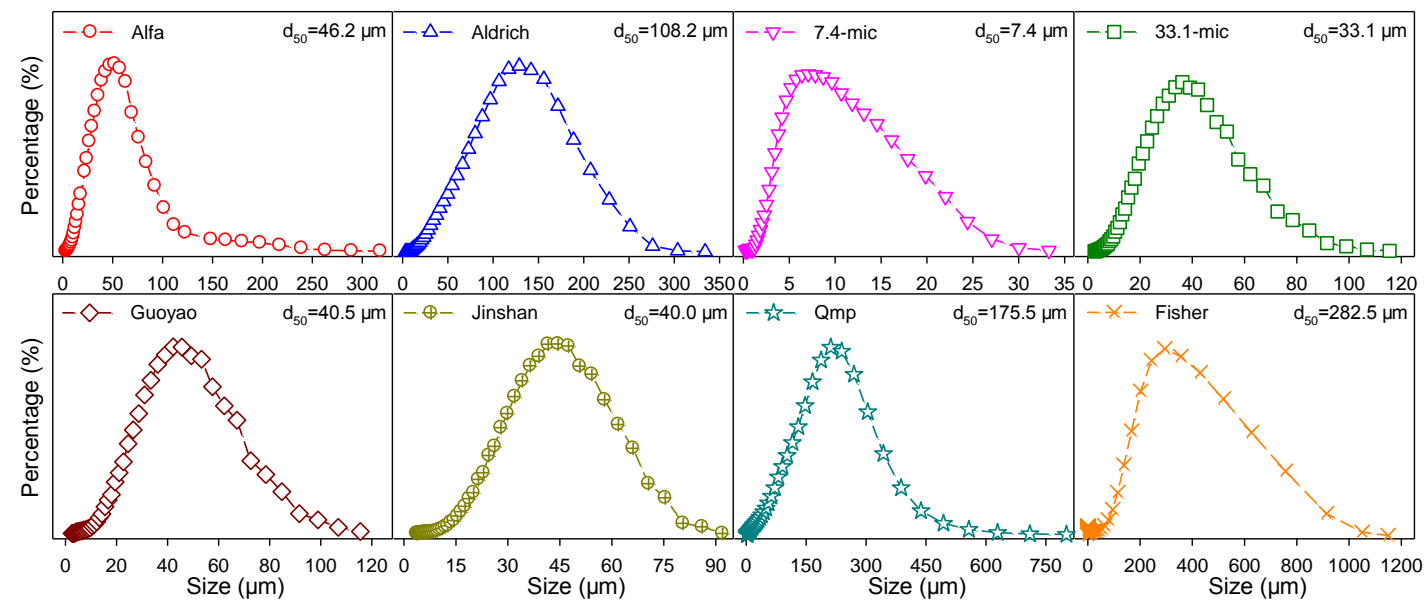

Figure S2. Particle size distribution of the ZVI samples employed in this study. 


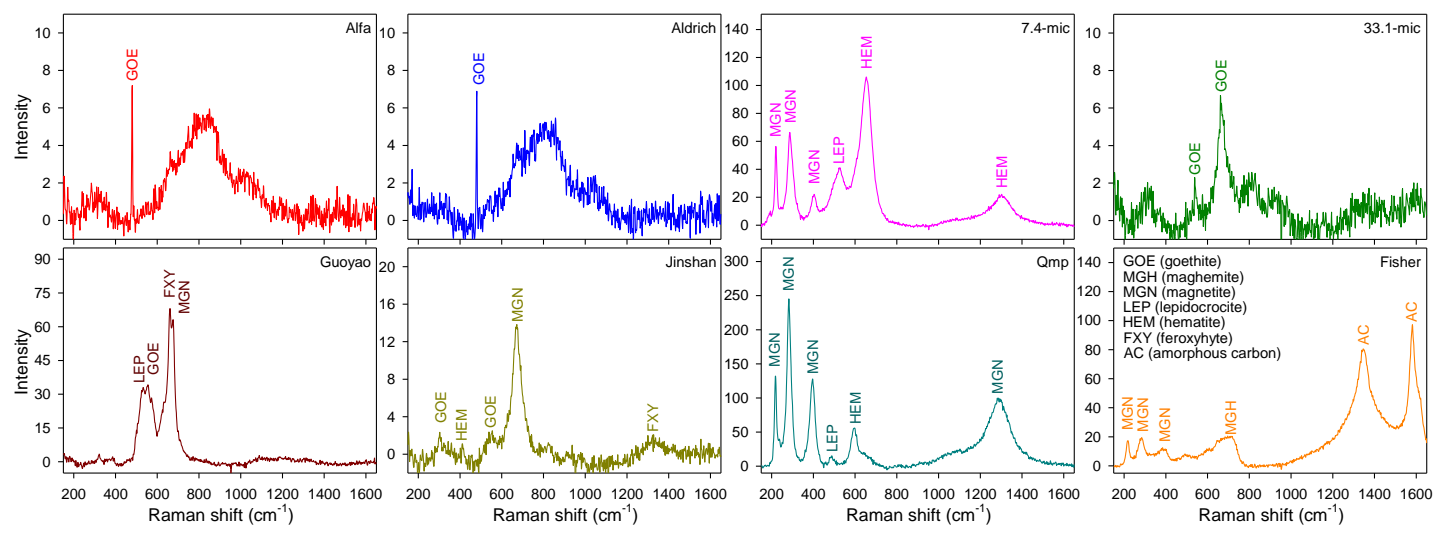

Figure S3. Raman spectra of the ZVI samples employed in this study. 


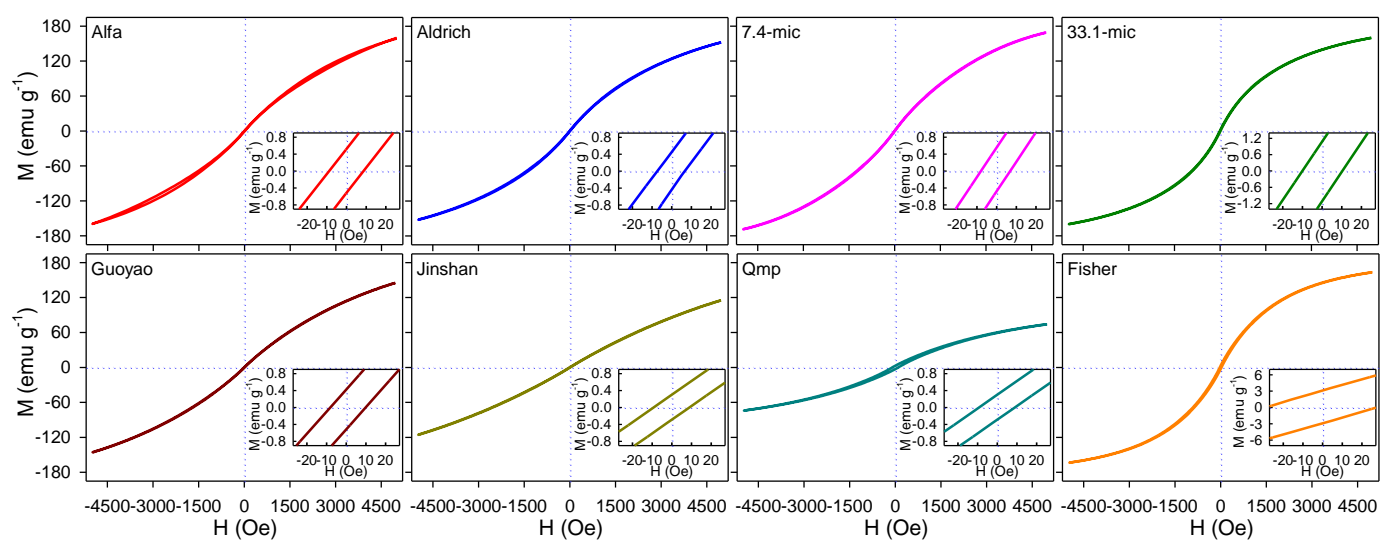

Figure S4. Magnetic hysteresis loops of the pristine ZVI samples recorded at $300 \mathrm{~K}$ $\left(\mathrm{B}_{\max }=500 \mathrm{mT}\right)$. The inset shows the behavior of the hysteresis loops in the low-field region. 

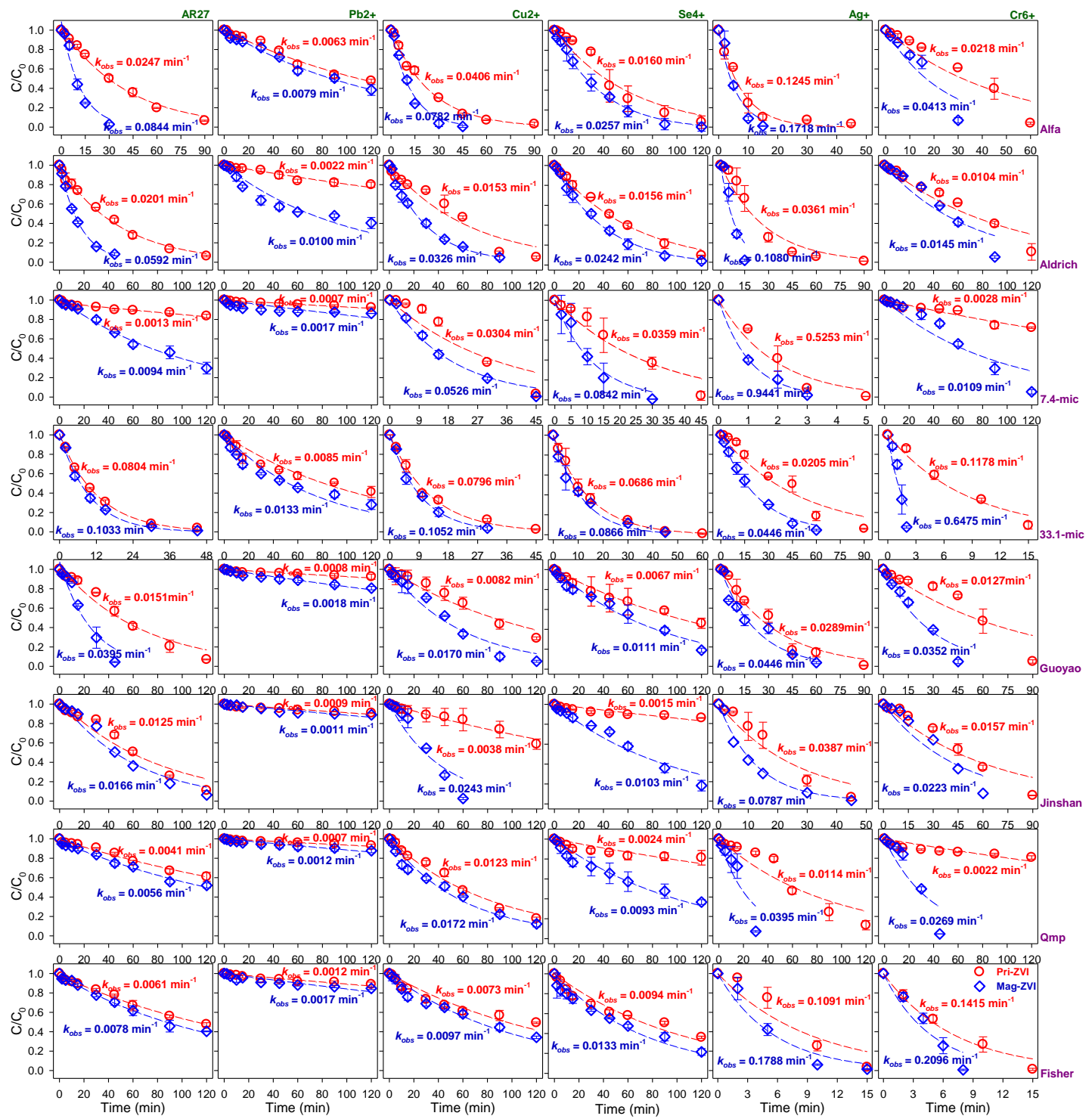

Figure S5. The kinetics of $\mathrm{AR} 27, \mathrm{~Pb} 2+, \mathrm{Cu} 2+, \mathrm{Se} 4+, \mathrm{Ag}+$ and $\mathrm{Cr} 6+$ removal by

Pri-ZVI and Mag-ZVI (Symbols are experimental data and dash lines are simulation results with the pseudo-first-order kinetic model), respectively. Reaction conditions: $\left[\mathrm{Fe}^{0}\right]=0.50 \mathrm{~g} \mathrm{~L}^{-1},[\mathrm{NaAc}-\mathrm{HAc}]=0.10 \mathrm{M}(\mathrm{pH} 4.0), \quad[$ Intensity of $\mathrm{MF}$ for premagnetization $]=500 \mathrm{mT}, \mathrm{t}_{\text {premag }}=2 \min , \mathrm{T}=25 \pm 1{ }^{\circ} \mathrm{C}$. 


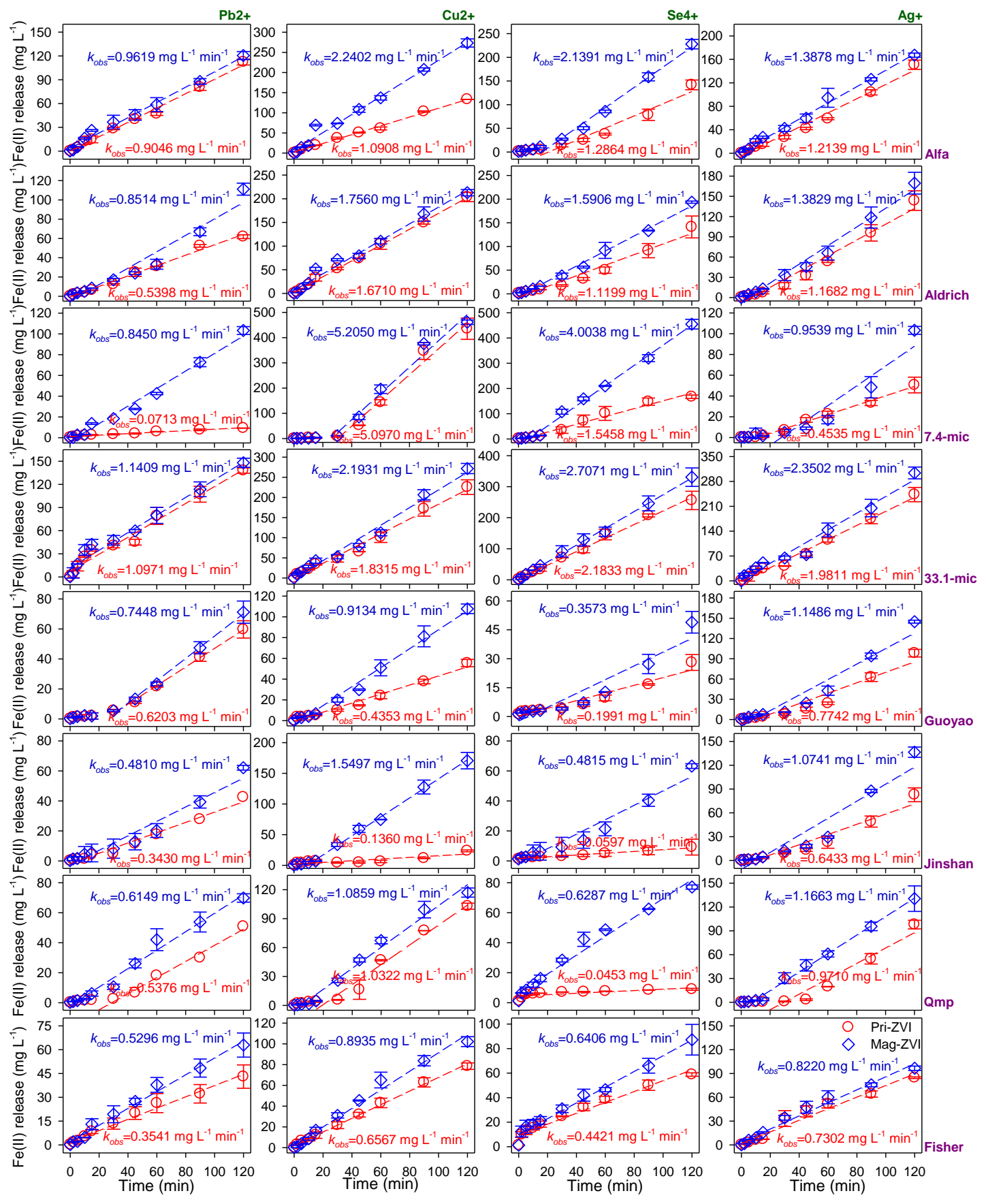

Figure S6. Release of dissolved $\mathrm{Fe}(\mathrm{II})$ during $\mathrm{Pb} 2+, \mathrm{Cu} 2+, \mathrm{Se} 4+$ and $\mathrm{Ag}+$ removal by

Pri-ZVI/Mag-ZVI samples. 


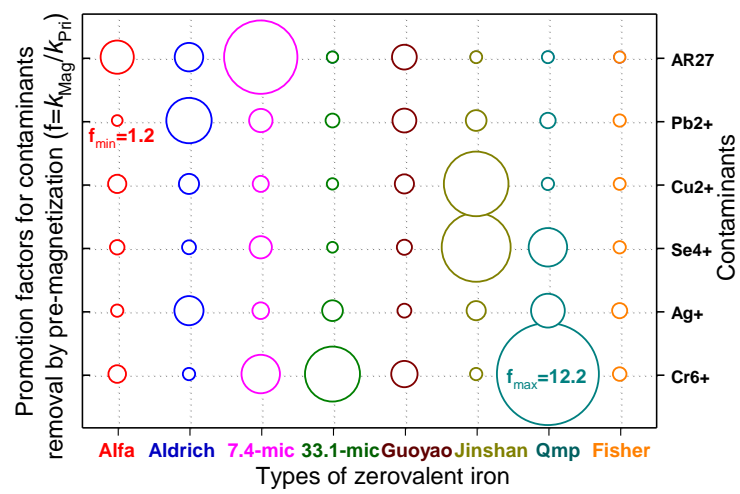

Figure S7. Bubble plot of the promotion factors ( $\mathrm{f}=k_{\mathrm{Mag}} / k_{\mathrm{Pri}}$, represented as ring size) for contaminants sequestration due to premagnetization plotted versus contaminants (ordinate) and the types of ZVI (abcissa). 


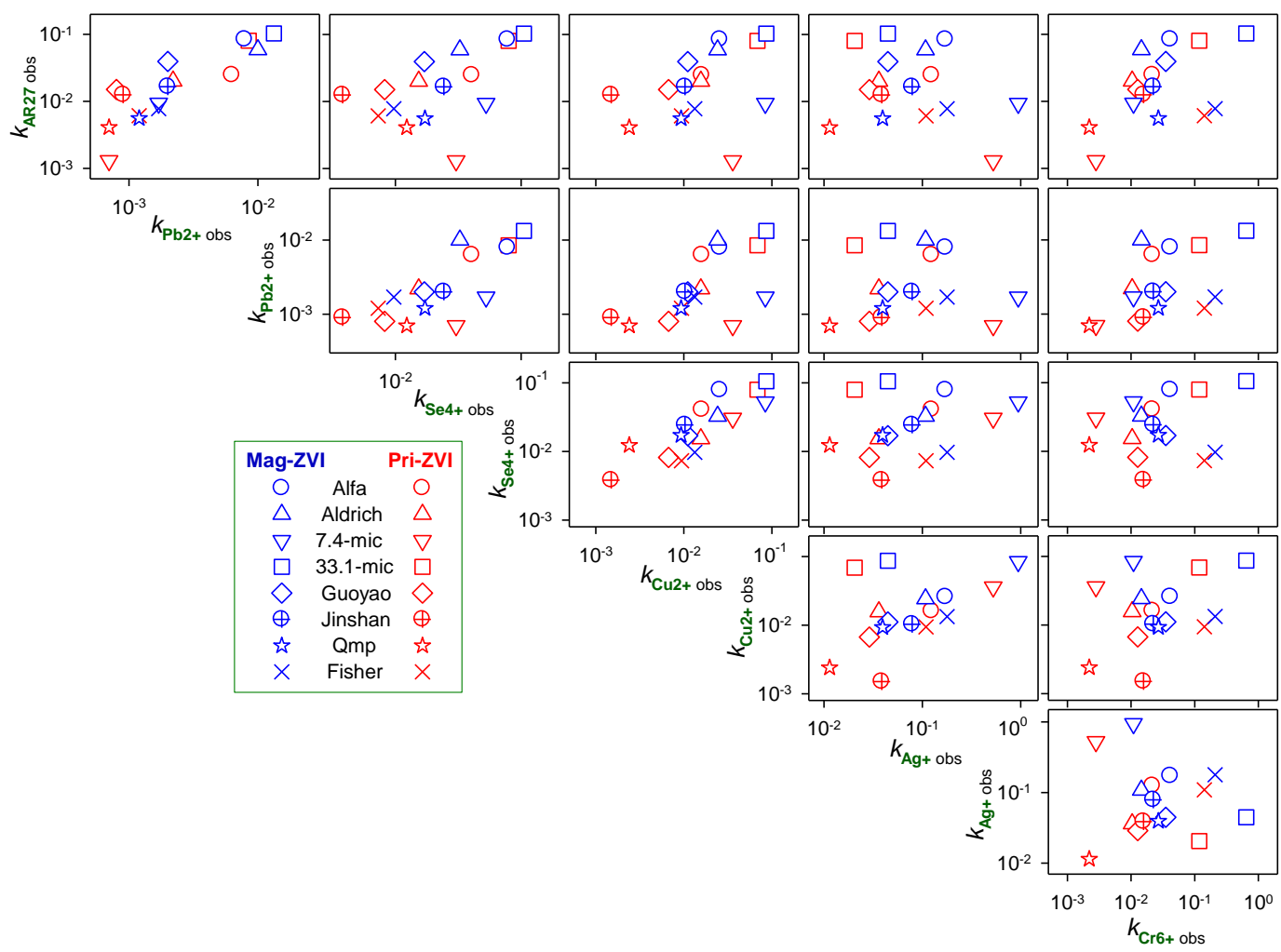

Figure S8. Scatter plot matrix of rate constants $\left(k_{\mathrm{obs}}, \mathrm{min}^{-1}\right)$ for all combinations of contaminants removal by Pri-ZVI and Mag-ZVI samples. Each symbol in each plot represents one of the eight types of ZVI. 


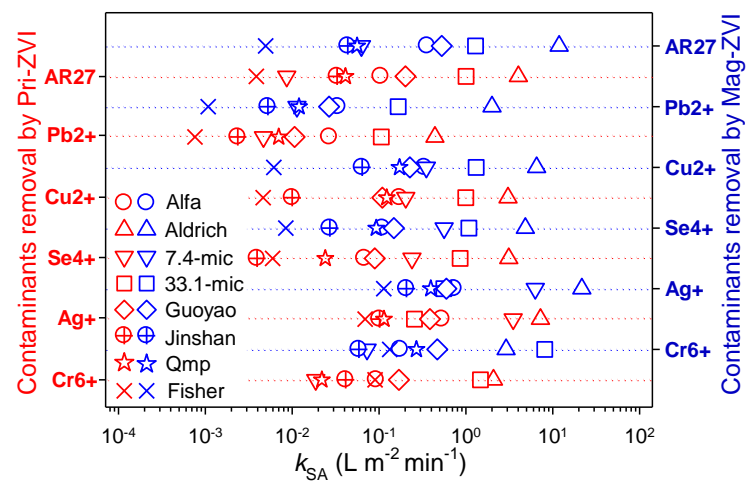

Figure S9. Rate constants $\left(k_{\mathrm{SA}}, \mathrm{L} \mathrm{m}^{-2} \mathrm{~min}^{-1}\right)$ of $\mathrm{Cr} 6+, \mathrm{Ag}+, \mathrm{Se} 4+, \mathrm{Cu} 2+, \mathrm{Pb} 2+$ and AR27 sequestrated by Pri-ZVI (left ordinate) and Mag-ZVI (right ordinate). 

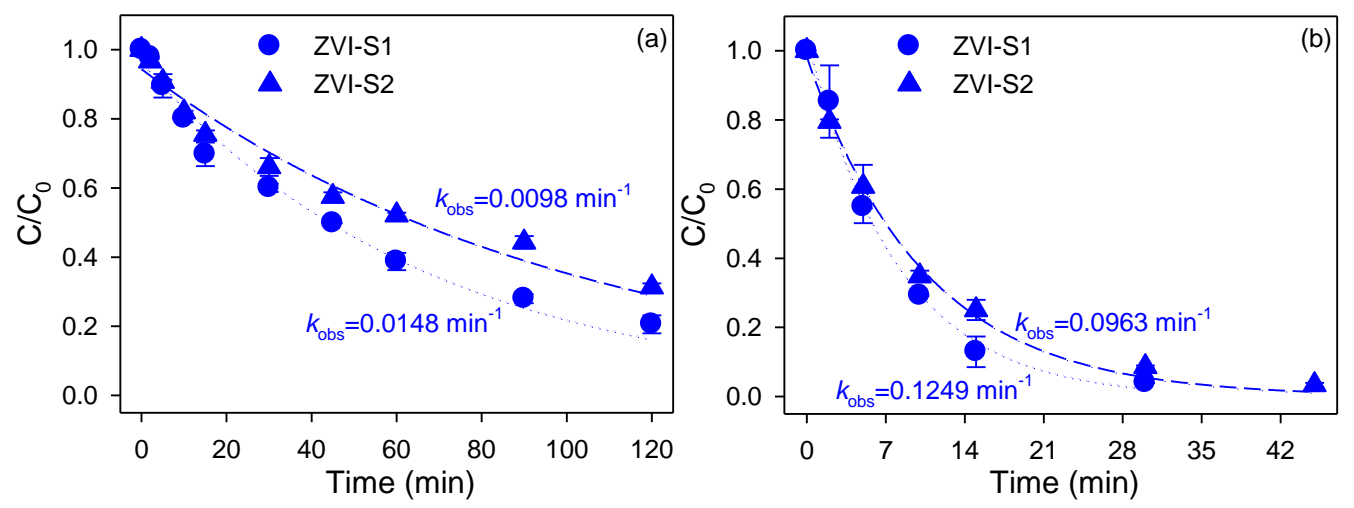

Figure S10. Kinetics of $\mathrm{Pb} 2+$ (a) and $\mathrm{Cu} 2+$ (b) removal by Mag-ZVI (ZVI-S1, specific surface area $($ SSA $)=0.40 \mathrm{~m}^{2} \mathrm{~g}^{-1}$ and ZVI-S2, SSA $\left.=2.41 \mathrm{~m}^{2} \mathrm{~g}^{-1}\right)$. Symbols are experimental data and dash lines are simulation results with the pseudo-first-order kinetic model. Reaction conditions: $\left[\mathrm{Fe}^{0}\right]=0.50 \mathrm{~g} \mathrm{~L}^{-1},[\mathrm{Cu} 2+/ \mathrm{Pb} 2+]=0.20 \mathrm{mM}$, $[\mathrm{NaAc}-\mathrm{HAc}]=0.10 \mathrm{M}(\mathrm{pH} 4.0),[$ Intensity of $\mathrm{MF}$ for premagnetization $]=500 \mathrm{mT}$, $\mathrm{t}_{\text {premag }}=2 \min , \mathrm{T}=25 \pm 1{ }^{\circ} \mathrm{C}$. 


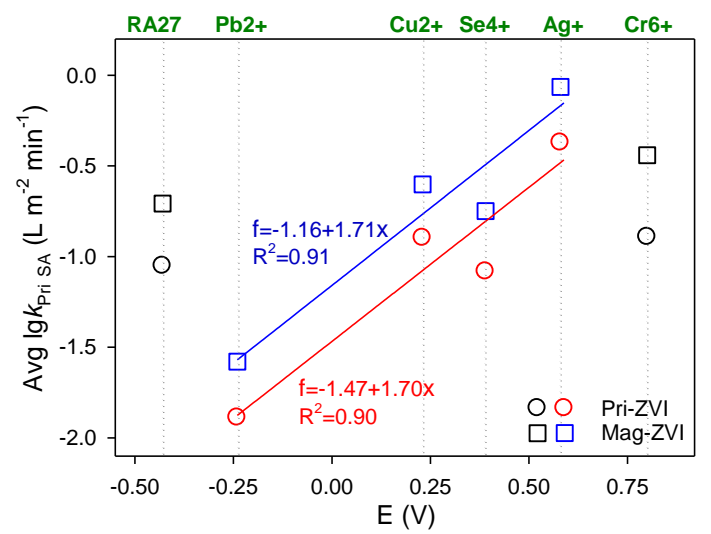

Figure S11. The relationship between the average rate constants (Avg $\log k_{\mathrm{SA}}, \mathrm{L} \mathrm{m}^{-2}$ $\min ^{-1}$ ) of each contaminant by all types of ZVI samples and the redox potentials $(\mathrm{E}, \mathrm{V})$ of these contaminants (abcissa). 


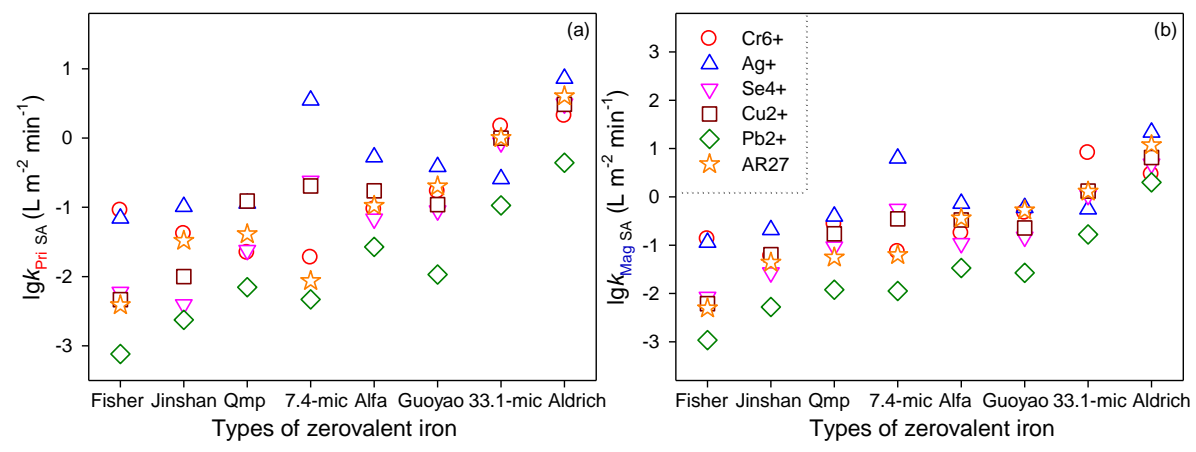

Figure S12. Rate constants $\left(\lg k_{\mathrm{SA}}, \mathrm{L} \mathrm{m}^{-2} \mathrm{~min}^{-1}\right)$ for disappearance of $\mathrm{Cr} 6+, \mathrm{Ag}+$, Se4+, Cu2+, Pb2+ and AR27 by Pri-ZVI (a) and Mag-ZVI (b). 


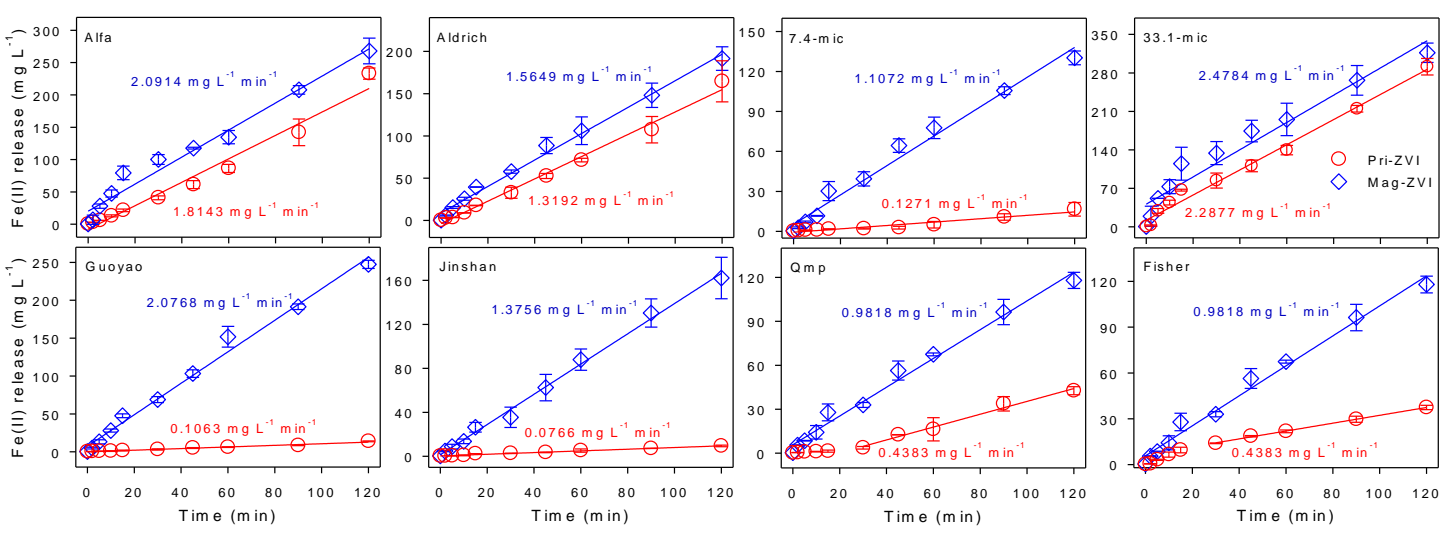

Figure S13. The kinetics of Fe(II) release from the Pri-ZVI and Mag-ZVI samples employed in this study without the presence of contaminants. The solid lines are the results of simulation with zero-order rate law and the numbers are the observed rate constants of Fe(II) release from Pri-ZVI and Mag-ZVI samples. Reaction conditions: $\left[\mathrm{Fe}^{0}\right]=0.50 \mathrm{~g} \mathrm{~L}^{-1},[\mathrm{NaAc}-\mathrm{HAc}]=0.10 \mathrm{M}(\mathrm{pH}=4.0), \quad[$ Intensity of MF for premagnetization $]=500 \mathrm{mT}, \mathrm{t}_{\mathrm{premag}}=2 \mathrm{~min}, \mathrm{~T}=25 \pm 1{ }^{\circ} \mathrm{C}$. 


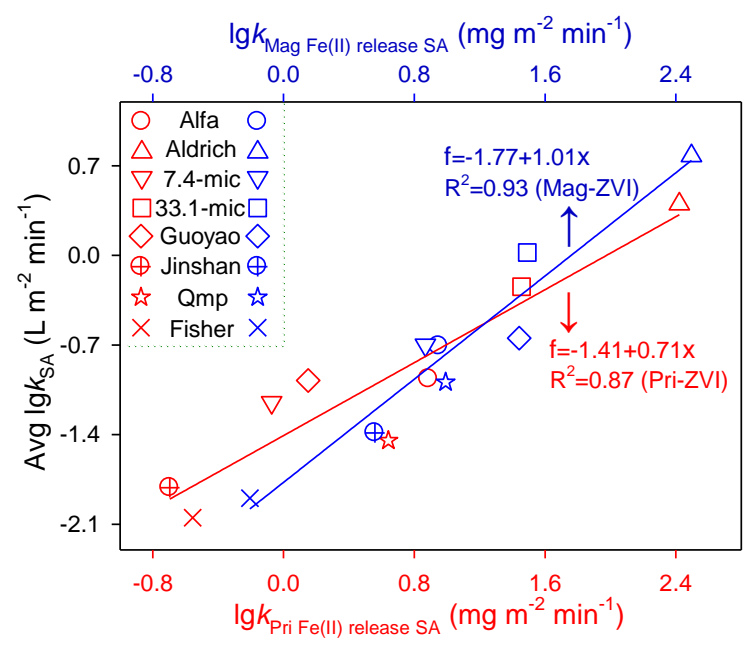

Figure S14. The correlation of the average rate constants $\left(\operatorname{Avg} \lg k_{\mathrm{SA}}, \mathrm{L} \mathrm{m}^{-2} \mathrm{~min}^{-1}\right)$ for all combinations of contaminants with the $\mathrm{Fe}(\mathrm{II})$ release rates $\left(\lg k_{\mathrm{Fe}(\mathrm{II}) \text { releaseSA, } \mathrm{mg}}\right.$ $\mathrm{m}^{-2} \mathrm{~min}^{-1}$ ) of the Pri-ZVI and Mag-ZVI from different origins. 

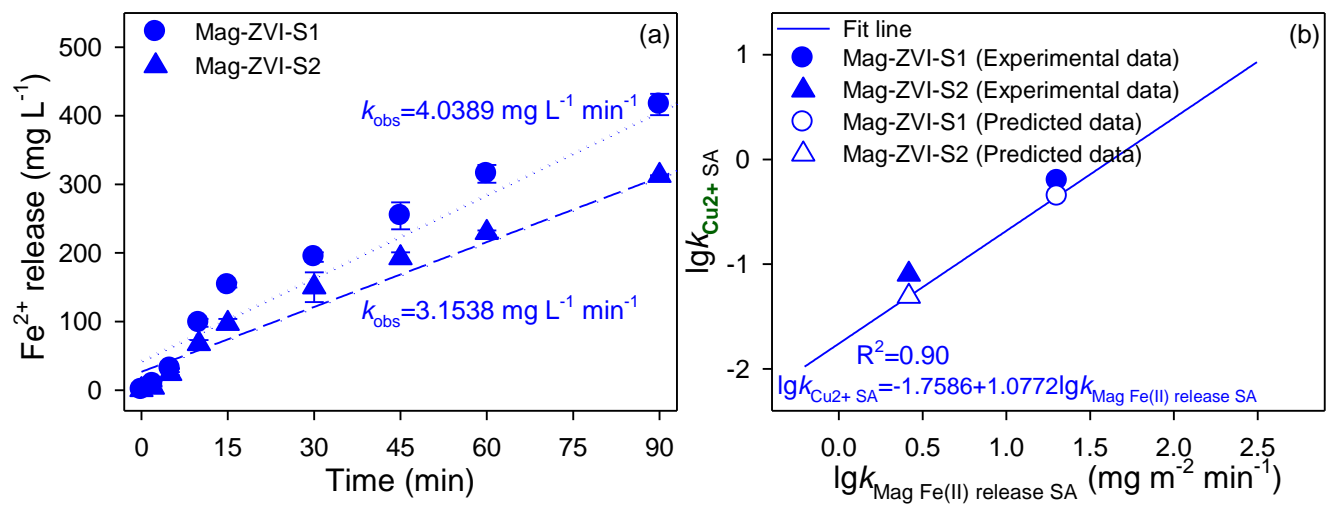

Figure S15. (a) The kinetics of Fe(II) release from two Mag-ZVI samples (ZVI-S1, $\mathrm{SSA}=0.40 \mathrm{~m}^{2} \mathrm{~g}^{-1}$ and ZVI-S2, SSA $=2.41 \mathrm{~m}^{2} \mathrm{~g}^{-1}$ ) without the presence of contaminants; (b) The consistency of the experimentally determined values of $\lg k_{\mathrm{Cu} 2+\mathrm{SA}}$ by two Mag-ZVI samples (not included in Figure 2(b)) with those predicted from the correlation illustrated in Figure 4. Reaction conditions: $\left[\mathrm{Fe}^{0}\right]=$ $0.50 \mathrm{~g} \mathrm{~L}^{-1},[\mathrm{NaAc}-\mathrm{HAc}]=0.10 \mathrm{M}(\mathrm{pH}=4.0)$, [Intensity of MF for premagnetization] $=500 \mathrm{mT}, \mathrm{t}_{\text {premag }}=2 \mathrm{~min}, \mathrm{~T}=25 \pm 1{ }^{\circ} \mathrm{C},[\mathrm{Cu} 2+]=0 \mathrm{mM}$ for $(\mathrm{a})$ and $[\mathrm{Cu} 2+]=0.20$ $\mathrm{mM}$ for (b). 


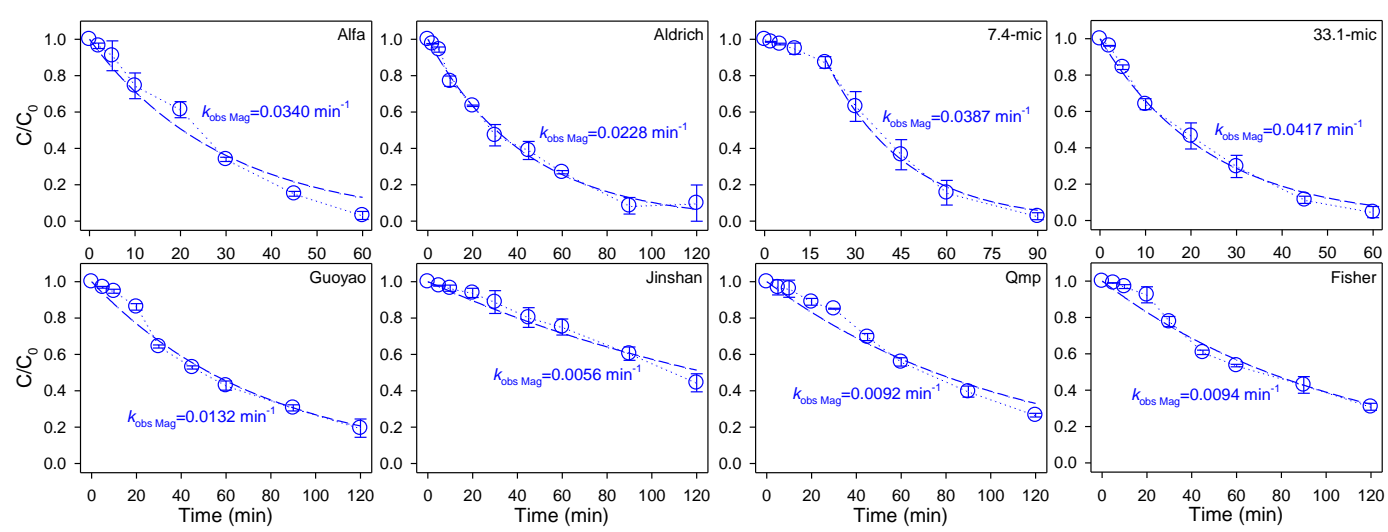

Figure S16. Kinetics of $\mathrm{Cu} 2+$ removal by various Mag-ZVI samples at $\mathrm{pH} 5.0$ (Symbols are experimental data and dash lines are simulation results with the pseudo-first-order kinetic model). Reaction conditions: $\left[\mathrm{Fe}^{0}\right]=0.50 \mathrm{~g} \mathrm{~L}^{-1},[\mathrm{Cu} 2+]=$ $0.20 \mathrm{mM},[\mathrm{NaAc}-\mathrm{HAc}]=0.10 \mathrm{M}(\mathrm{pH} 5.0),[$ Intensity of MF for premagnetization $]=$ $500 \mathrm{mT}, \mathrm{t}_{\text {premag }}=2 \mathrm{~min}, \mathrm{~T}=25 \pm 1{ }^{\circ} \mathrm{C}$. 


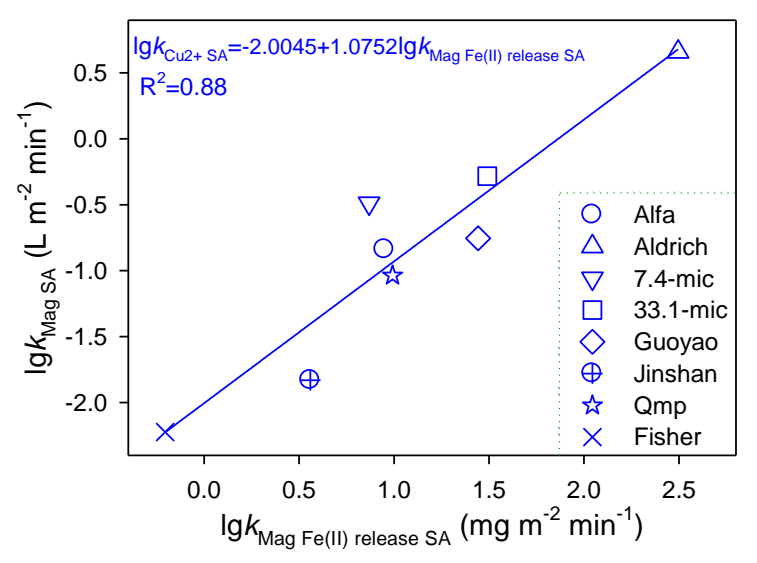

Figure S17. The correlation of the specific rate constants $\left(\lg k_{\mathrm{Mag} \mathrm{SA}}, \mathrm{L} \mathrm{m}^{-2} \mathrm{~min}^{-1}\right)$ for $\mathrm{Cu} 2+$ removal by Mag-ZVI ( $\mathrm{pH}$ 5.0) with the intrinsic reactivity of Mag-ZVI samples $\left(\lg k_{\text {Mag Fe(II)release SA }}, \mathrm{mg} \mathrm{m}^{-2} \min ^{-1}\right)$. 

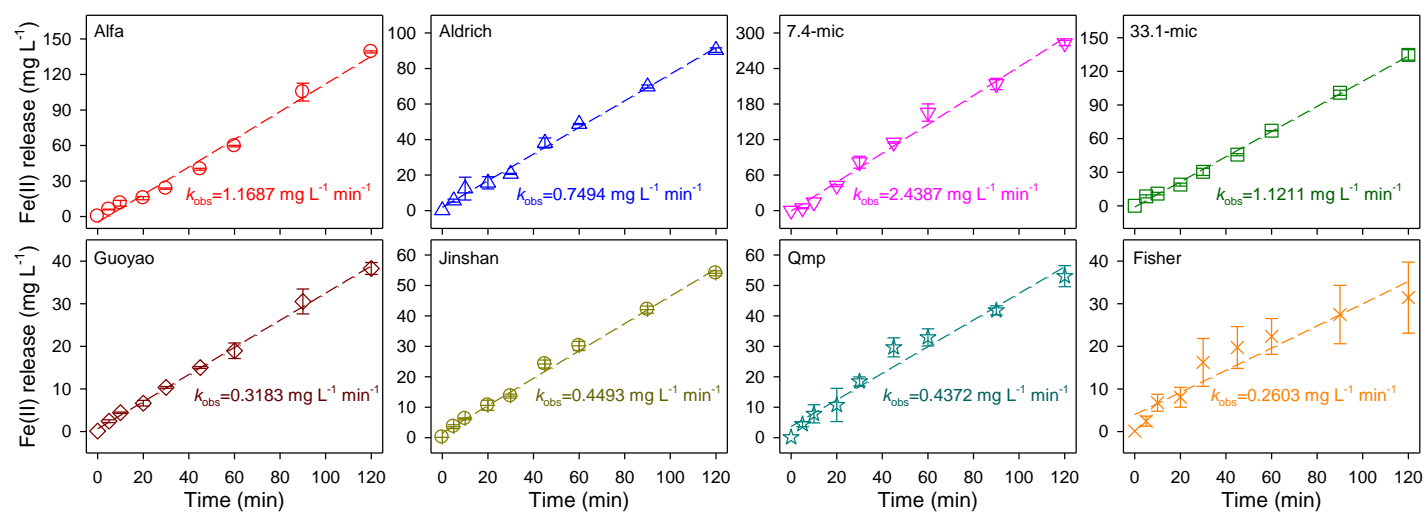

Figure S18. The kinetics of $\mathrm{Fe}(\mathrm{II})$ release from the Mag-ZVI samples under nitrogen-purging conditions without the presence of contaminants. The dashed lines are the results of simulation with zero-order rate law and the numbers are the observed rate constants of $\mathrm{Fe}(\mathrm{II})$ release from the Mag-ZVI samples. Reaction conditions: $\left[\mathrm{Fe}^{0}\right]=0.50 \mathrm{~g} \mathrm{~L}^{-1},[\mathrm{NaAc}-\mathrm{HAc}]=0.10 \mathrm{M}(\mathrm{pH}=4.0)$, [Intensity of MF for premagnetization $]=500 \mathrm{mT}, \mathrm{t}_{\text {premag }}=2 \mathrm{~min}, \mathrm{~T}=25 \pm 1{ }^{\circ} \mathrm{C}$. 


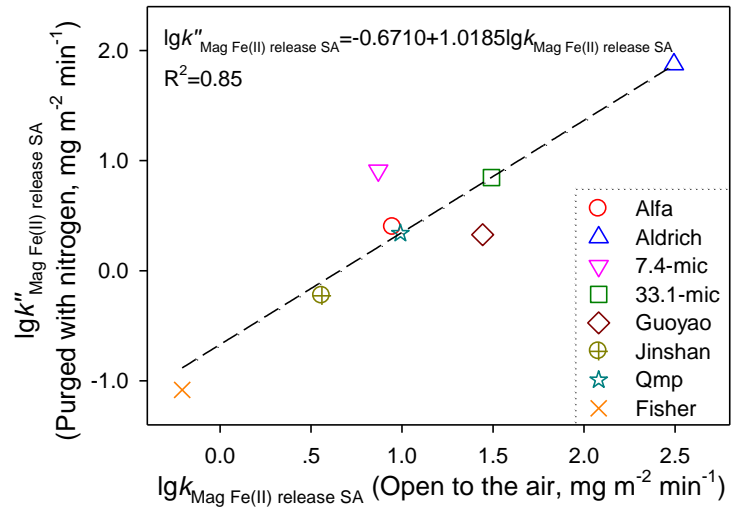

Figure S19. Correlation of the Fe(II) release rates of various Mag-ZVI samples under

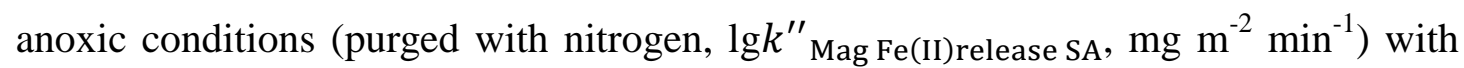
the intrinsic reactivity (open to the air, $\lg k_{\mathrm{Mag} \text { Fe(II)release SA }}, \mathrm{mg} \mathrm{m}^{-2} \mathrm{~min}^{-1}$ ) of these Mag-ZVI samples. 
Table S1. Properties of contaminants employed in this study (0.10 M NaAc-HAc buffer system, $\mathrm{pH} 4.0$ ).

\begin{tabular}{ccccc}
\hline Contaminants & Abbr. & Half reactions & $\mathrm{E} / \mathrm{V}$ & $\chi_{\mathrm{m}}{ }^{\mathrm{a}} / 10^{-6} \mathrm{~cm}^{3} \mathrm{~mol}^{-1}$ \\
\hline Chromate & $\mathrm{Cr6}+$ & $\mathrm{HCrO}_{4}^{-}+7 \mathrm{H}^{+}+3 \mathrm{e}^{-} \leftrightarrow \mathrm{Cr}^{3+}+4 \mathrm{H}_{2} \mathrm{O}$ & +0.80 & +55.0 \\
Silver ion & $\mathrm{Ag}+$ & $\mathrm{Ag}^{+}+\mathrm{e}^{-} \leftrightarrow \mathrm{Ag}$ & +0.58 & -92.9 \\
Selenite & $\mathrm{Se} 4+$ & $\mathrm{HSeO}_{3}^{-}+5 \mathrm{H}^{+}+4 \mathrm{e}^{-} \leftrightarrow \mathrm{Se}+3 \mathrm{H}_{2} \mathrm{O}$ & +0.39 & -27.2 \\
Copper ion & $\mathrm{Cu} 2+$ & $\mathrm{Cu}^{2+}+2 \mathrm{e}^{-} \leftrightarrow \mathrm{Cu}$ & +0.23 & +1080.0 \\
Lead ion & $\mathrm{Pb} 2+$ & $\mathrm{Pb}^{2+}+2 \mathrm{e}^{-} \leftrightarrow \mathrm{Pb}$ & -0.24 & -73.8 \\
Amaranth & $\mathrm{AR} 27$ & $\mathrm{AR} 27+4 \mathrm{H}^{+}+4 \mathrm{e}-\leftrightarrow \mathrm{A}+\mathrm{R}^{\mathrm{b}}$ & -0.43 & n.d \\
\hline
\end{tabular}

${ }^{\mathrm{a}} \chi_{\mathrm{m}}$ is the molar magnetic susceptibility.

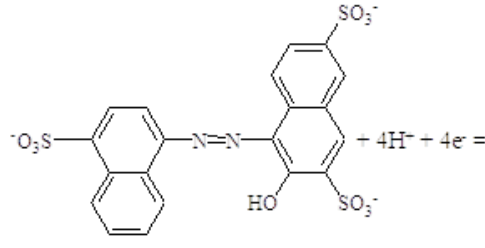

b $\mathrm{AR} 27$<smiles>Nc1ccc(Br)c2ccccc12</smiles>

A

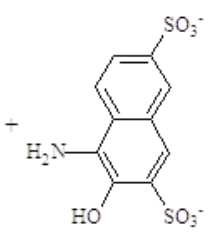

R

${ }^{\mathrm{c}}$ n.d. $=$ not determined. 
Table S2. The mean observed rate constants $\left(k_{\mathrm{obs}}, \mathrm{min}^{-1}\right)$ for contaminants sequestration by Pri-ZVI and Mag-ZVI.

\begin{tabular}{ccc}
\hline Contaminants & $\begin{array}{c}\text { Mean } \\
/ k_{\text {Pri obs }}\end{array}$ & $\begin{array}{c}\text { Mean } \\
/ k_{\text {Mag obs }}\end{array}$ \\
\hline $\mathrm{Cr} 6+$ & 0.041 & 0.126 \\
$\mathrm{Ag}+$ & 0.112 & 0.201 \\
$\mathrm{Se} 4+$ & 0.020 & 0.033 \\
$\mathrm{Cu} 2+$ & 0.025 & 0.042 \\
$\mathrm{~Pb} 2+$ & 0.003 & 0.005 \\
$\mathrm{AR} 27$ & 0.021 & 0.041 \\
\hline
\end{tabular}


Table S3. Statistics of the normal distribution calculated by the One-Sample Kolmogorov-Smirnov Test.

\begin{tabular}{|c|c|c|c|c|c|c|c|c|c|c|c|c|c|c|c|}
\hline & & $\begin{array}{c}\lg k_{\mathrm{SA}} \\
\text { AR27 Pri }\end{array}$ & $\begin{array}{c}\lg k_{\mathrm{SA}} \\
\text { AR27 Mag }\end{array}$ & $\begin{array}{c}\lg k_{\mathrm{SA}} \\
\mathrm{Pb} 2+\mathrm{Pri}\end{array}$ & $\begin{array}{c}\lg k_{\mathrm{SA}} \\
\mathrm{Pb} 2+\mathrm{Mag}\end{array}$ & $\begin{array}{c}\lg k_{\mathrm{SA}} \\
\mathrm{Cu} 2+\mathrm{Pri}\end{array}$ & $\begin{array}{c}\lg k_{\mathrm{SA}} \\
\mathrm{Cu} 2+\mathrm{Mag}\end{array}$ & $\begin{array}{c}\lg k_{\mathrm{SA}} \\
\text { Se4+ Pri }\end{array}$ & $\begin{array}{c}\lg k_{\mathrm{SA}} \\
\mathrm{Se} 4+\mathrm{Mag}\end{array}$ & $\begin{array}{c}\lg k_{\mathrm{SA}} \\
\mathrm{Ag}+\operatorname{Pri}\end{array}$ & $\begin{array}{c}\lg k_{\mathrm{SA}} \\
\mathrm{Ag}+\mathrm{Mag}\end{array}$ & $\begin{array}{c}\lg k_{\mathrm{SA}} \\
\mathrm{Cr} 6+\text { Pri }\end{array}$ & $\begin{array}{c}\lg k_{\mathrm{SA}} \\
\mathrm{Cr} 6+\mathrm{Mag}\end{array}$ & $\begin{array}{c}\lg k_{\mathrm{SA}} \\
\text { Pri Fe(II) release }\end{array}$ & $\begin{array}{c}\lg k_{\mathrm{SA}} \\
\operatorname{Mag} \mathrm{Fe}(\mathrm{II}) \text { release }\end{array}$ \\
\hline $\mathrm{N}$ & & 8 & 8 & 8 & 8 & 8 & 8 & 8 & 8 & 8 & 8 & 8 & 8 & 8 & 8 \\
\hline $\begin{array}{l}\text { Normal } \\
\text { Parameters }\end{array}$ & Mean & -1.052 & -.707 & -1.888 & -1.580 & -.897 & -.601 & -1.082 & -.749 & -.371 & -.064 & -.891 & -.441 & .529 & 1.074 \\
\hline Std. Derivation & & 1.010 & 1.042 & .895 & .989 & .930 & .888 & 1.005 & .884 & .731 & .759 & .772 & .762 & 1.052 & .783 \\
\hline \multirow[t]{3}{*}{ Most Extreme } & Absolute & .130 & .183 & .162 & .207 & .223 & .184 & .122 & .161 & .198 & .288 & .197 & .192 & .140 & .172 \\
\hline & Positive & .130 & .183 & .162 & .207 & .163 & .184 & .122 & .161 & .198 & .288 & .197 & .192 & .140 & .172 \\
\hline & Negative & -.101 & -.141 & -.096 & -.115 & -.223 & -.177 & -.094 & -.125 & -.145 & -.123 & -.165 & -.150 & -.122 & -.146 \\
\hline \multicolumn{2}{|c|}{ Kolmogorov-Smirnov Z } & .368 & .517 & .459 & .586 & .630 & .522 & .345 & .456 & .560 & .813 & .558 & .544 & .396 & .487 \\
\hline \multicolumn{2}{|c|}{ Asymp. (2-tailed) } & .999 & .952 & .984 & .882 & .823 & .948 & 1.000 & .985 & .913 & .522 & .914 & .929 & .998 & .972 \\
\hline
\end{tabular}

a. Test distribution is Normal.

b. Calculated from data. 
Table S4. Summary of the statistical significances derived from the Pearson correlation and Spearman correlation.

\begin{tabular}{|c|c|c|c|c|}
\hline \multirow{2}{*}{ Name } & \multicolumn{2}{|c|}{ Pri-ZVI } & \multicolumn{2}{|c|}{ Mag-ZVI } \\
\hline & $\mathrm{R}_{\mathrm{P}}^{2}$ & $\mathrm{R}_{\mathrm{S}}^{2}$ & $\mathrm{R}_{\mathrm{P}}^{2}$ & $\mathrm{R}_{\mathrm{S}}^{2}$ \\
\hline $\lg k_{\mathrm{AR} 27 \mathrm{SA}} \mathrm{Vs} \lg k_{\mathrm{Pb} 2+\mathrm{SA}}$ & 0.90 & 0.91 & 0.95 & 0.91 \\
\hline $\lg k_{\mathrm{AR} 27 \mathrm{SA}} \mathrm{vs} \lg k_{\mathrm{Cu} 2+\mathrm{SA}}$ & 0.68 & 0.48 & 0.88 & 0.82 \\
\hline $\lg k_{\mathrm{AR} 27 \mathrm{SA}} \mathrm{Vs} \lg k_{\mathrm{Se} 4+} \mathrm{SA}$ & 0.60 & 0.51 & 0.77 & 0.86 \\
\hline $\lg k_{\mathrm{AR}} 27 \mathrm{SA}$ vs $\lg k_{\mathrm{Ag}+\mathrm{SA}}$ & 0.11 & 0.30 & 0.47 & 0.58 \\
\hline $\lg k_{\mathrm{AR} 27 \mathrm{SA}} \mathrm{Vs} \lg k_{\mathrm{Cr} 6+\mathrm{SA}}$ & 0.73 & 0.69 & 0.60 & 0.66 \\
\hline $\lg k_{\mathrm{Pb} 2+\mathrm{SA}}$ vs $\lg k_{\mathrm{Cu} 2+\mathrm{SA}}$ & 0.88 & 0.69 & 0.92 & 0.73 \\
\hline $\lg k_{\mathrm{Pb} 2+\mathrm{SA}}$ Vs $\lg k_{\mathrm{Se} 4+\mathrm{SA}}$ & 0.80 & 0.66 & 0.84 & 0.69 \\
\hline $\lg k_{\mathrm{Pb} 2+\mathrm{SA}} \mathrm{vs} \lg k_{\mathrm{Ag}+\mathrm{SA}}$ & 0.22 & 0.48 & 0.56 & 0.48 \\
\hline $\lg k_{\mathrm{Pb} 2+\mathrm{SA}}$ vs $\lg k_{\mathrm{Cr} 6+\mathrm{SA}}$ & 0.65 & 0.58 & 0.63 & 0.69 \\
\hline $\lg k_{\mathrm{Cu} 2+\mathrm{SA}} \mathrm{Vs} \lg k_{\mathrm{Se} 4+\mathrm{SA}}$ & 0.92 & 0.82 & 0.93 & 0.96 \\
\hline $\lg k_{\mathrm{Cu} 2+\mathrm{SA}} \mathrm{vs} \lg k_{\mathrm{Ag}+\mathrm{SA}}$ & 0.40 & 0.66 & 0.65 & 0.73 \\
\hline $\lg k_{\mathrm{Cu} 2+\mathrm{SA}}$ Vs $\lg k_{\mathrm{Cr} 6+\mathrm{SA}}$ & 0.40 & 0.18 & 0.48 & 0.38 \\
\hline $\lg k_{\mathrm{Se} 4+} \mathrm{SA}$ Vs $\lg k_{\mathrm{Ag}+\mathrm{SA}}$ & 0.66 & 0.66 & 0.75 & 0.69 \\
\hline $\lg k_{\mathrm{Se} 4+\mathrm{SA}}$ Vs $\lg k_{\mathrm{Cr} 6+\mathrm{SA}}$ & 0.50 & 0.33 & 0.50 & 0.44 \\
\hline $\lg k_{\mathrm{Ag}+\mathrm{SA}}$ vs $\lg k_{\mathrm{Cr} 6+\mathrm{SA}}$ & 0.11 & 0.10 & 0.11 & 0.11 \\
\hline $\lg k_{\mathrm{AR}} 27 \mathrm{SA}$ Vs $\lg k_{\mathrm{Fe}(\mathrm{II})}$ release SA & 0.78 & 0.73 & 0.93 & 0.86 \\
\hline $\lg k_{\mathrm{Pb} 2+\mathrm{SA}}$ vs $\lg k_{\mathrm{Fe}(\mathrm{II}) \text { release SA }}$ & 0.93 & 0.91 & 0.93 & 0.86 \\
\hline $\lg k_{\mathrm{Cu} 2+\mathrm{SA}}$ vs $\lg k_{\mathrm{Fe}(\mathrm{II})}$ release SA & 0.86 & 0.69 & 0.90 & 0.62 \\
\hline $\lg k_{\mathrm{Se} 4+\mathrm{SA}}$ vs $\lg k_{\mathrm{Fe}(\mathrm{II})}$ release SA & 0.75 & 0.62 & 0.82 & 0.69 \\
\hline $\lg k_{\mathrm{Ag}+\mathrm{SA}} \operatorname{vs} \lg k_{\mathrm{Fe}(\mathrm{II})}$ release SA & 0.35 & 0.38 & 0.57 & 0.35 \\
\hline $\lg k_{\mathrm{Cr} 6+\mathrm{SA}}$ vs $\lg k_{\mathrm{Fe}(\mathrm{II}) \text { release SA }}$ & 0.59 & 0.48 & 0.71 & 0.82 \\
\hline
\end{tabular}

$\mathrm{R}_{\mathrm{P}}$ : The correlation coefficient of Pearson correlation;

$\mathrm{R}_{\mathrm{S}}$ : The correlation coefficient of Spearman correlation. 